\title{
Association between Overexpression of Her-2 and Other Clinicopathologic Prognostic Factors in Breast Cancer in Morocco"
}

\author{
Zineb Bouchbika\#, Nadia Benchakroun, Amina Taleb, Hassan Jouhadi, Nezha Tawfiq, \\ Souha Sahraoui, Abdellatif Benider \\ Department of Radiotherapy Oncology, Ibn Rochd University Hospital and Hassan II University, Casablanca, Morocco. \\ Email: "bouchbika_zineb@yahoo.fr, nadbenchakroun@yahoo.fr, taleb.amina@yahoo.fr, hjouhadi@yahoo.fr, tawfiqnezha@yahoo.fr, \\ sahraouisouha@gmail.com, beniderabdel@yahoo.fr
}

Received August $9^{\text {th }}, 2012$; revised September $12^{\text {th }}, 2012$; accepted September $22^{\text {nd }}, 2012$

\begin{abstract}
Background: Breast cancer is the leading cancer among women. The management depends largely on the knowledge of prognostic factors. The aim of our study is to evaluate the overexpression of Her-2/neu in patients with invasive breast carcinoma in Morocco, and to study the association between this overexpression and otherprognostic factors of breast cancer, such as age, tumor size, tumor grade, hormone receptors, vascular space invasion and lymph node status. Methods: This is a transversal study in which we included patients with invasive breast carcinomas treated at University Hospital Ibn Rochd of Casablanca in radiotherapy-oncology departement between January 2008 and December 2010, having had surgery first. Univariate analysis (Chi 2 test and Student's test) and multivariate (logistic regression) were performed to study this association. Results: The overexpression of Her-2/neu was found in $29.2 \%$ of cases. In univariate analysis, Her-2 positive status was significantly correlated with high-grade tumors and large, to a lymph node, vascular space invasion and negative ER/PR. Age alone does not appear as a factor associated with positive Her-2/neu status. In multivariate analysis, the overexpression of Her 2 was significantly associated only with vascular space invasion, high tumor grade and the negativity of estrogen receptors. Conclusion: In our series, only the high grade, the vascular space invasion and the negative hormone receptors are independent factors associated with overexpression of Her-2/neu. Age does not appear as a factor associated with positive Her-2/neu status.
\end{abstract}

Keywords: Breast Cancer; Her-2/Neu; Prognosis Factors

\section{Background}

Breast cancer is the most common cancer in women with more than a million new cases per year worldwide, representing $22 \%$ of all cancers diagnosed in women [1]. It is the leading cause of cancer death worldwide with over 370,000 deaths per year, or $14 \%$ of cancer deaths in women [2].

Breast cancer is characterized by great diversity in clinical expression and histological forms of the disease. Several prognostic factors are defined: we distinguish classical prognostic factors, or first-generation and newer prognostic factors such as oncogene Her 2 (human epidermal growth factor receptor 2).

The HER-2 gene encodes a $185 \mathrm{kDa}$ transmembrane phosphoglycoprotein with tyrosine kinase activity and is a member of the human epidermal growth factor receptor gene family [3]. Her-2/neu (c-erbB-2) gene amplification,

\footnotetext{
${ }^{*}$ Conflict of interest: all authors have no conflicts of interest.
}

${ }^{\#}$ Corresponding author. which usually results in overexpression of the encoded transmembrane protein, occurs in approximately $20 \%$ to $30 \%$ of invasive breast cancers [4-9]. Cells transfected with HER-2/neu acquire a more malignant phenotype, with stimulation of cell proliferation, invasion, and metastasis [10]. This has been confirmed in the clinic: women with HER-2/neu positive breast cancer have a worse prognosis than those with HER-2/neu negative cancers [11-14].

Several controversies available in the literature regarding the correlation between protein overexpression Her $2 /$ neu and other prognosis factors. In our context, there is no data regarding this correlation. The aim of our study is to evaluate the overexpression of Her-2/neu in patients with invasive breast carcinoma in Morocco, and to study the association between this overexpression and other prognostic factors of breast cancer: age, tumor size, histological grade, hormone receptors, vascular space invasion and lymph node. 


\section{Methods}

This is a transversal study in which we included patients with invasive breast carcinomas treated at Ibn Rochd University Hospital of Casablanca in the department of radiotherapy-oncology between January 2008 and December 2010. Concerning the inclusion criteria, medical records were reviewed retrospectively: patients treated for relapse or who have received neoadjuvant chemotherapy, and medical records with missing data on the tumor characteristics were excluded. Our study concerned the only cases for which we had complete information about the patient and the tumor.

The following factors were studied: patient age at diagnosis, tumor size, tumor grade, vascular space invasion, axillary lymph node status, extra capsular spread, hormone receptors and Her-2/neu status. The histological type is specified according to WHO classification of breast cancer [15] and the histological grading was performed using the modified criteria of Bloom and Richardson, as described by Elston and Ellis [16].

The hormone receptor status and Her-2/neu was defined by immunohistochemistry. A semi-quantitative histochemical score was used to record results of ER and PR staining according to the system established by Allred et al. [17]. This system considers both the proportion and intensity of stained cells. The intensity score (IS) ranges from 0 to 3 , with 0 being no staining, 1 weak staining, 2 intermediate staining, and 3 intense staining. The proportion score (PS) estimates the proportion of positive tumor cells and ranges from 0 to 5 , with 0 being non-reacting, 1 for $1 \%$ reacting tumor cells, 2 for $10 \%$ reacting tumor cells, 3 for one-third reacting tumor cells, 4 for twothirds reacting tumor cells, and 5 if $100 \%$ of tumor cells show reactivity. The PS and IS are added to obtain a total score (TS) that ranges from 0 to 8 . Tumor cells with a total score of 3 to 8 were considered positive, whereas those with a TS less than 3 were considered negative cases.

Her-2/neu was scored on a 0 to 3 scale according to the criteria set by Dako. The staining was scored as: negative (0) when no membrane staining was observed, or when membranous staining was observed in less than $10 \%$ of the tumor cells; weak positive (1+) if weak focal membrane staining was seen in more than $10 \%$ of the tumor cells; intermediate ( $2+$ ) if weak to moderate, complete membrane staining was seen in more than $10 \%$ of the tumor cells; and strongly positive (3+) if intense membrane staining with weak to moderate cytoplasmic reactivity was seen in more than $10 \%$ of the tumor cells.

In the final analysis, scores 0 and 1 were considered negative, score 2 was considered weakly positive and score 3 was considered strongly positive. Only score 3 cases were considered as Her-2 overexpressing cases. In our study, a FISH or CISH was performed in all patients with a $2+$ score.

We used a univariate and multivariate analysis to study the correlation between overexpression of Her-2/ neu protein and other clinicopathological prognostic factors. A descriptive analysis of clinicopathological variables was performed: the numbers and percentages were calculated (categorical variables) and the mean $+/-$ standard deviation (quantitative variables). The Chi-square test (categorical variables) and Student's test (quantitative variables) were used to study the association between Her-2/neu status and other clinicopathological variables. In multivariate analysis, logistic regression was used to detect the independent factors correlated with overexpression of Her 2/neu protein. Statistical analyses were performed using SPSS. Results were considered statistically significant if the $\mathrm{p}$ value was $<0.05$.

The study began after the women agreed themselves to participate in our study. Patients who refused to participate in this study were not included.

\section{Results}

Between January 2008 and December 2010, 2014 patients with invasive breast carcinoma were treated in our structure: 1508 patients were selected for this study. Table 1 sums up all the clinical and pathological features of patients in this study, with invasive breast carcinoma who underwent first surgery.

The mean age of patients was 48.4 years $+/-10.6$ years. The percentage of patients aged under 35 was $10.4 \%$. The majority of tumors was classified as T3 (56.3\%), and $40.1 \%$ of tumors showed no nodal involvement.

On the therapeutic level, breast conserving surgery was performed on $28.6 \%$ of patients and a systemic treatment was indicated for $95.2 \%$ of patients while radiotherapy was indicated on $90.6 \%$ of patients.

Overexpression of the protein Her-2/neu was observed in $29.2 \%$ of patients. The $2+$ score was found in $5.3 \%$ (79) of patients: a FISH or CISH was performed demonstrating a gene amplification in only $24 \%$ (19) of patients.

In univariate analysis (Table 2), the Her-2 positive status was significantly correlated with large and high graded tumors, with lymph node, in the presence of vascular space invasion and with negative ER/PR. Age alone does not appear as a factor associated with positive Her-2/neu status. Extra capsular spread in case of nodal involvement was also analyzed in our study and proved to be a factor significantly correlated with HER-2 positive status. Extra capsular spread was found in 58\% of Her-2 positive patients versus $45 \%$ for Her- 2 negative patients $(p=0.0003)$. The percentage of metastatic patient at the diagnosis was higher in the HER-2 positive group 
Table 1. Clinicopathological characteristics breast carcinoma $(N=1508)$.

\begin{tabular}{|c|c|c|}
\hline Clinicopathological features & $\mathrm{N}$ & $\%$ \\
\hline \multicolumn{3}{|l|}{ Age (years) } \\
\hline$-\leq 35$ & 157 & 10.4 \\
\hline$->35$ & 1341 & 89.6 \\
\hline \multicolumn{3}{|c|}{$\begin{array}{l}\text { Tumor grade (medullary carcinoma } \\
\text { excluded) }\end{array}$} \\
\hline$-\mathrm{I}+\mathrm{II}$ & 1073 & 72.4 \\
\hline - III & 409 & 27.6 \\
\hline \multicolumn{3}{|l|}{ Tumor size } \\
\hline$-\leq 5 \mathrm{~cm}$ & 1240 & 82.2 \\
\hline$->5 \mathrm{~cm}$ & 268 & 17.8 \\
\hline \multicolumn{3}{|l|}{ Lymph node } \\
\hline - positive & 905 & 60 \\
\hline - with extra capsular spread & 443 & 49 \\
\hline \multicolumn{3}{|l|}{ Vascular space invasion } \\
\hline - yes & 722 & 47.9 \\
\hline - No & 786 & 52.1 \\
\hline \multicolumn{3}{|l|}{ Her-2/neu status } \\
\hline - positive & 440 & 29.2 \\
\hline - negative & 1068 & 70.8 \\
\hline \multicolumn{3}{|l|}{ ER expression } \\
\hline - positive & 929 & 61.6 \\
\hline - negative & 579 & 38.4 \\
\hline \multicolumn{3}{|l|}{ PR expression } \\
\hline - positive & 880 & 58.4 \\
\hline - negative & 628 & 44.6 \\
\hline \multicolumn{3}{|l|}{ Histologic type } \\
\hline - Ductal & 1370 & 90.8 \\
\hline - Non ductal & 138 & 9.2 \\
\hline \multicolumn{3}{|l|}{ Metastatic status } \\
\hline - M0 & 1385 & 91.8 \\
\hline - M1 & 123 & 8.2 \\
\hline
\end{tabular}

Her2 = human epidermal growth factor receptor 2; ER = estrogen receptor; $\mathrm{PR}=$ progesterone receptor.

compared to the Her-2 negative one: $9.4 \%$ versus $7.7 \%$, but this difference was not statistically significant $(\mathrm{p}=$ 0.29 ).

In multivariate analysis (Table 3), the overexpression of Her 2 was significantly associated only with the presence of vascular space invasion, high grade tumor and with negative oestrogene receptors.

\section{Discussion}

Breast cancers have a tumoral heterogeneity on the clinical, histological and molecular level explaining the diversity of presentations, responses to treatment and of prognosis. The management of breast cancer depends largely on the knowledge of prognostic factors. Currently
Table 2. Association between overexpression of Her2 protein and clinicopathological characteristics $(\mathrm{N}=1508)$ : univariate Analysis.

\begin{tabular}{|c|c|c|c|}
\hline \multirow{2}{*}{$\begin{array}{l}\text { Clinicopathological } \\
\text { features }\end{array}$} & \multicolumn{3}{|c|}{ Her-2/neu expression } \\
\hline & Positive n (\%) & Negative N (\%) & $\mathrm{p}$ \\
\hline \multicolumn{4}{|l|}{ Age (years) } \\
\hline$-\leq 35$ & $51(11.6)$ & $106(9.9)$ & \multirow[t]{2}{*}{0.33} \\
\hline$->35$ & $389(88.4)$ & $962(90.1)$ & \\
\hline Mean age & $48.1+/-10.8$ & $48.52+/-10.5$ & 0.48 \\
\hline \multicolumn{4}{|c|}{$\begin{array}{l}\text { Tumor grade (medullary } \\
\text { carcinoma excluded) }\end{array}$} \\
\hline$-\mathrm{I}+\mathrm{II}$ & $288(66.2)$ & $785(75)$ & \multirow{2}{*}{$<0.001$} \\
\hline - III & $147(33.8)$ & $262(25)$ & \\
\hline \multicolumn{4}{|l|}{ Tumor size } \\
\hline$-\leq 5 \mathrm{~cm}$ & $343(78)$ & $897(84)$ & \\
\hline$->5 \mathrm{~cm}$ & $97(22)$ & $171(16)$ & 0.005 \\
\hline \multicolumn{4}{|l|}{ Lymph node } \\
\hline - negative & $157(35.7)$ & $446(41.8)$ & \multirow[t]{2}{*}{0.002} \\
\hline - positive & $283(64.3)$ & $622(58.2)$ & \\
\hline \multicolumn{4}{|c|}{ Vascular space invasion } \\
\hline - missing & $244(55.5)$ & $478(44.8)$ & \multirow{2}{*}{$<0.001$} \\
\hline - present & $196(44.5)$ & $590(55.2)$ & \\
\hline \multicolumn{4}{|l|}{ ER expression } \\
\hline - positive & $221(50.2)$ & $708(66.3)$ & \multirow{2}{*}{$<0.001$} \\
\hline - negative & $219(49.2)$ & $360(33.7)$ & \\
\hline \multicolumn{4}{|l|}{ PR expression } \\
\hline - positive & $209(47.5)$ & $671(62.7)$ & \multirow[t]{2}{*}{$<0.001$} \\
\hline - negative & $231(52.5)$ & $397(37.3)$ & \\
\hline
\end{tabular}

Her2 = human epidermal growth factor receptor 2; ER = estrogen receptor; $\mathrm{PR}=$ progesterone receptor.

the prognostic factors of breast cancers can be divided into first-generation prognostic factors, such as lymph node status, tumor size, tumor grade, hormonal status and the second generation prognostic factors among which the growth factor receptors (Her2). The latter constitute, with hormonal receptors, prognostic and predictive factors of response or resistance to therapy (Trastuzumab in the case of overexpression of the protein Her-2/neu) $[18,19]$. These new prognostic and predictive factors of response to treatment are necessary to distinguish subgroups of patients with different biological characteristics and who before appeared homogeneous according to clinical pathological and classical prognostic factors. The absence of data in our context concerning the frequency of overexpression Her 2 and its association with other prognostic factors motivated this study in order to identify the prognostic profile of our patients. In 1987, Slamon et al. [11] showed that gene amplification was 
Table 3. Association between overexpression of Her2 protein and clinicopathological characteristics $(N=1508)$ : multivariate Analysis.

\begin{tabular}{lccc}
\hline Clinicopathological features & Odds ratio & $95 \%$ CI & $\mathrm{p}$ \\
\hline Age $(>35$ versus $\leq 35$ years) & 1.00 & $0.99-1.01$ & 0.87 \\
Tumor size $(>5 \mathrm{v} \leq 5 \mathrm{~cm})$ & 1.19 & $0.88-1.60$ & 0.25 \\
$\begin{array}{l}\text { Tumor grade ( III v I - II) } \\
\begin{array}{l}\text { Vascular space invasion } \\
\text { (present v missing) }\end{array}\end{array}$ & 1.28 & $1.00-1.65$ & 0.05 \\
$\begin{array}{l}\text { Lymph node (positive v } \\
\text { negative) }\end{array}$ & 1.21 & $0.95-1.54$ & 0.13 \\
$\begin{array}{l}\text { ER expression (positive v } \\
\text { negative) }\end{array}$ & 0.51 & $0.41-0.65$ & $<0.001$ \\
\hline
\end{tabular}

Her2 = human epidermal growth factor receptor 2; ER = estrogen receptor.

significantly correlated with poor prognosis: early relapse and shorter survival. This correlation persisted after adjustment for lymph node status and other prognostic factors in multivariate analysis. In our series, we found that $29.2 \%$ of patients were Her-2positive. Although there is great variation in the HER-2 overexpression and gene amplification, our frequency seems to be commonly accepted within the range from 20 to $30 \%$ [4-9]. However, this frequency remains higher compared to our neighbors the tunisians where it is $18.1 \%$ [20]. The analysis of the association between overexpression of Her-2/neu and other prognostic factors revealed the following findings:

In univariate analysis, tumor grade, tumor size, lymph node involvement, vascular space invasion and negative estrogen receptors were significantly correlated with overexpression of the protein Her-2/neu.

While in multivariate analysis, only the tumor grade, the vascular space invasion and the negative estrogen receptors appear to be independent factors associated with protein overexpression Her-2/neu.

Several studies have demonstrated that overexpression of the protein Her-2/neu was correlated with younger age [21-26]. Our study did not permit to show this correlation: $11.6 \%$ of patients HER-2 positive were younger than 35 years versus $9.9 \%$ for Her- 2 negative patients but the difference was not statistically significant. The mean age of our patients was 48.4 years (+/- 10.6 years) which is significantly younger than what is currently in Western considered countries. This can be explained by the young age of our population [low life expectancy compared to Western countries] or by the risk factors that may be specific to our country. Tumor size is an important prognostic factor that is directly correlated with survival. Our study showed a statistically significant correlation between HER-2 status and tumor size in only univariate analysis. This pattern of overexpression of Her-2 in large tumors has been demonstrated in other studies $[27,28]$ while in some studies this association has not been found [24,29-32]. The prognostic value of grade is currently established. Hoff et al. demonstrated in their series that high-grade tumors were more likely to have a positive HER-2 status as low-grade tumors [33]. Similarly, other studies have also reported the association between HER-2 positive status and a high histological grade [29-31]. This finding was also confirmed in our study. However, some studies have not demonstrated any correlation between high-grade status and HER-2 positive $[24,34]$.The axillary lymph node involvement is a major prognostic factor. Most studies that have examined the prognostic role of HER-2 in $\mathrm{N}+$ patients showed that amplification of HER-2 gene or overexpression of Her-2/ neu protein is associated with pejorative results whether in univariate or multivariate analysis [35-37]. Our study found this association in univariate analysis, but disappeared in multivariate analysis. Extra capsular spread and the vascular space invasion are two parameters that have been poorly studied in the literature and found to be associated with overexpression of the protein Her-2/neu in our study. Despite the vast differences at the levels of the positivity of the Her-2, all the researchers report an inverse correlation between HER-2 status and the hormone receptors [24,28-30,32,35,38-42]. Our data are consistent with those reported in the literature.

\section{Conclusion}

The analysis of HER-2 status is important in the management of breast cancer because it provides valuable prognostic, predictive and therapeutic information. In our study $29.2 \%$ of tumors overexpress Her-2/neu. This number, although in the normal range, is still high compared to other countries. A prospective study with centralization hercept test in trained laboratory pathology could more accurately estimate the frequency of overexpression of Her-2/neu. In this study, the overexpression of Her-2 was significantly correlated with tumor size, tumor grade, lymph node involvement with extra capsular spread, vascular space invasion and hormone receptor negativity. Our study did not reveal any association between HER-2 positive status and young age: perhaps because the young age of our population with breast cancer (mean age 48 years) or because of the size of the sample. Further studies are required to answer this question.

\section{REFERENCES}

[1] I. B. Ghorbela, S. C. Kanouna, A D. Kallela, A. B. Belaida, F. Azourya, S. Heymanna, et al., "Cancer du 
Sein Sans Atteinte Ganglionnaire Axillaire," Cancer/ Radiothérapie, Vol. 14, Suppl. 1, 2010, pp. S127-S135.

[2] B. Trétarre, A. V. Guizard and D. Fontaine, "Cancer du Sein Chez la Femme: Incidence et Mortalité, France 2000," BEH, Vol. 44, 2004, pp. 209-210.

[3] T. Akiyama, C. Sudo, H. Ogawara, et al., "The Product of the Human c-erbB-2 Gene: A 185-Kilodalton Glycoprotein with Tyrosine Kinase Activity," Science, Vol. 232, No. 4758, 1986, pp. 1644-1646. doi:10.1126/science.3012781

[4] D. J. Slamon, W. Godolphin, L. A. Jones, J. A. Holt, S. G. Wong, D. E. Keith, et al., "Studies of the Her-2/Neu Proto-Oncogene in Human Breast and Ovarian Cancer," Science, Vol. 244, No. 4905, 1989, pp. 707-712. doi:10.1126/science. 2470152

[5] G. Pauletti, W. Godolphin, M. F. Press and D. J. Slamon, "Detection and Quantitation of Her-2/Neu Gene Amplification in Human Breast Cancer Archival Material Using Fluorescence in Situ Hybridization," Oncogene, Vol. 13, No. 1, 1996, pp. 63-72.

[6] T. Rajkumar and W. J. Gullick, "The Type I Growth Factor Receptors in Human Breast Cancer," Breast Cancer Research and Treatment, Vol. 29, No. 1, 1994, pp. 3-9. doi:10.1007/BF00666177

[7] C. R. De Potter and A. M. Schelfhout, "The Neu-Protein and Breast Cancer," Virchows Arch, Vol. 426, No. 2, 1995, pp. 107-115.

[8] G. Pauletti, S. Dandekar, H. Rong, L. Ramos, H. Peng, R. Seshadri and D. J. Slamon, "Assessment of Methods for Tissue-Based Detection of the Her-2/Neu Alteration in Human Breast Cancer: A Direct Comparison of Fluorescence in Situ Hybridization and Immunohistochemistry," Journal of Clinical Oncology, Vol. 18, No. 21, 2000, pp. 3651-3664.

[9] D. Varshney, Y. Y. Zhou, S. A. Geller and R. Alsabeh, "Determination of HER-2 Status and Chromosome 17 Polysomy in Breast Carcinomas Comparing HercepTest and PathVysion FISH Assay," American Journal of Clinical Pathology, Vol. 121, No. 1, 2004, pp. 70-77. doi:10.1309/FUQH92B039025LHG

[10] C. C. Benz, G. K. Scott, J. C. Sarup, et al., "EstrogenDependent, Tamoxifen-Resistant Tumorigenic Growth of MCF-7 Cells Transfected with Her-2/Neu," Breast Cancer Research and Treatment, Vol. 24, No. 2, 1993, pp. 85-95. doi:10.1007/BF01961241

[11] D. J. Slamon, G. M. Clark, S. G. Wong, W. J. Levin, A. Ullrich and W. L. McGuire, "Human Breast Cancer: Correlation of Relapse and Survival with Amplification of the Her-2/Neu Oncogene," Science, Vol. 235, No. 4785, 1987, pp. 177-182. doi:10.1126/science.3798106

[12] B. A. Gusterson, R. D. Gelber, A. Goldhirsch, et al., "Prognostic Importance of c-erbB-2 Expression in Breast Cancer," Journal of Clinical Oncology, Vol. 10, No. 7, 1992, pp. 1049-1056.

[13] P. Kronqvist, T. Kuopio, M. Nykanen, et al., "Predicting Aggressive Outcome in T1N0M0 Breast Cancer," British Journal of Cancer, Vol. 91, No. 2, 2004, pp. 277-281.
[14] S. B. Bull, H. Ozcelik, D. Pinnaduwage, et al., "The Combination of p53 Mutation and Neu/erbB-2 Amplification Is Associated with Poor Survival in Nodenegative Breast Cancer," Journal of Clinical Oncology, Vol. 22, No. 1, 2004, pp. 86-96. doi:10.1200/JCO.2004.09.128

[15] F. Tavassoli and P. Devilee, "World Health Organization Classification of Tumours. Pathology and Genetics of Tumours of the Breast and Female Genital Organs," IARC Press, Lyon, 2003.

[16] E. W. Elston and I. O. Ellis, "Method for Grading Breast Cancer," Journal of Clinical Pathology, Vol. 46, No. 2, 1993, pp. 189-190.

[17] D. C. Allred, J. M. Harvey, M. Berardo and G. M. Clark, "Prognostic and Predictive Factors in Breast Cancer by Immunohistochemical Analysis," Modern Pathology, Vol. 11, No. 2, 1998, pp. 155-168.

[18] S. J. Schnitt, "Traditional and Newer Pathologic Factors," Journal of the National Cancer Institute. Monographs, Vol. 2001, No. 30, 2001, pp. 22-26. doi:10.1093/oxfordjournals.jncimonographs.a003456

[19] D. Cameron and R. Bell, "Optimizing Treatment for Patients with Breast Cancer," Seminars in Oncology, Vol. 31, No. 10, 2004, pp. 4-5. doi:10.1053/j.seminoncol.2004.07.015

[20] L. Ayadi, A. Khabir, H. Amouri, S. Karray, A. Dammak, M. Guermazi and T. Boudawara, "Correlation of HER-2 Over-Expression with Clinico-Pathological Parameters in Tunisian Breast Carcinoma," World Journal of Surgical Oncology, Vol. 6, 2008, p. 112. doi:10.1186/1477-7819-6-112

[21] T. El-AHelal, A. Khalifa and A. S. Kamel, "Immunohistochemical Expression of p53 and cerbB2 Proteins in Breast Cancer in Egypt," Anticancer Research, 20, 3B, 2000, pp. 2145-2150.

[22] S. Taucher, M. Rudas, R. M. Mader, M. Gnant, P. Dubsky, T. Bachleitner, et al., "Do We Need Her-2/Neu Testing for All Patients with Primary Breast Carcinoma?" Cancer, Vol. 98, No. 12, 2003, pp. 2547-2553. doi:10.1002/cncr.11828

[23] S. Eppenberger-Castori, D. H. Moore Jr., A. D. Thor, S. M. Edgerton, W. Kueng, U. Eppenberger and C. C. Benz, "Age-Associated Biomarker Profiles of Human Breast Cancer," The International Journal of Biochemistry \& Cell Biology, Vol. 34, No. 11, 2002, pp. 1318-1330. doi:10.1016/S1357-2725(02)00052-3

[24] N. M. Almasri and M. Al Hamad, "Immunohistochemical Evaluation of Human Epidermal Growth Factor Receptor 2 and Estrogen and Progesterone Receptors in Breast Carcinoma in Jordan," Breast Cancer Research, Vol. 7, No. 5, 2005, pp. R598-R604. doi:10.1186/bcr1200

[25] H. J. Huang, P. Neven, M. Drijkoningen, R. Paridaens, H. Wildiers, E. Van Limbergen, et al., "Hormone Receptors Do Not Predict the Her-2/Neu Status in All Age Groups of Women with an Operable Breast Cancer," Annals of Oncology, Vol. 16, No. 11, 2005, pp. 1755-1761. doi:10.1093/annonc/mdi364

[26] B. K. Seo, E. D. Pisano, C M. Kusimak, M. Koomen, D. 
Pavic, Y. Lee, E. B. Cole and J. Y. Lee, "Correlation of Her-2/Neu Overexpression with Mammography and Age Distribution in Primary Breast Carcinomas," Academic Radiology, Vol. 13, No. 10, 2006, pp. 1211-1218. doi:10.1016/j.acra.2006.06.015

[27] J. M. Bhatavdekar, D. D. Patel, N. G. Shah, H. H. Vora, T. P. Suthar, P. R. Chikhlikar, et al., "Prognostic Significance of Immunohistochemically Localized Biomarkers in Stage II and Stage III Breast Cancer: A Multivariate Analysis," Annals of Surgical Oncology, Vol. 7, No. 4, 2000, pp. 305-311. doi:10.1007/s10434-000-0305-5

[28] T. Ivkovic-Kapicl, S. Knezevic-Usaj, D. Djilas-Ivanovic and M. Panjkovic, "Correlation of Her-2/Neu Protein Overexpression with Other Prognostic and Predictive Factors in Invasive Ductal Breast Cancer," Anticancer Research, Vol. 21, No. 4, 2007, pp. 673-678

[29] R. Prati, S. K. Apple, J. He, J. A. Gornbei and H. R. Chanh, "Histopathologic Characteristics Predicting Her2/Neu Amplification in Breast Cancer," Breast Journal, Vol. 11, No. 6, 2005, pp. 433-439. doi:10.1111/j.1075-122X.2005.00125.x

[30] H. J. Huang, P. Neven, M. Drijkoningen, R. Paridaens, H. Wildiers, E. Van Limberger, P. Berteloot, F. Amant, I. Vergote and M. R. Christiaens, "Association between Tumour Characteristics and Her-2/Neu by Immunohistochemistry in 1362 Women with Primary Operable Breast Cancer," Journal of Clinical Pathology, Vol. 58, No. 6, 2005, pp. 611-616. doi:10.1136/jcp.2004.022772

[31] S. Paik, J. Brayant, C. Park, B. Fisher, E. Tan-Chiu, D. Hyams, et al., "ErbB-2 and Response to Doxorubicin in Patients with Axillary Lymph-Node Positive, Hormone Receptor-Negative Breast Cancer," Journal of the National Cancer Institute, Vol. 90, No. 18, 1998, pp. 13611370. doi:10.1093/jnci/90.18.1361

[32] R. Ariga, A. Zarif, J. Korasick, V. Reddy, K. Siziopikou and P. Gattuso, "Correlation of Her-2/Neu Gene Amplification with Other Prognostic and Predictive Factors in Female Breast Carcinoma," Breast Journal, Vol. 11, No. 4, 2005, pp. 278-280. doi:10.1111/j.1075-122x.2005.21463.x

[33] E. R. Hoff, R. R. Tubbs, J. L. Myles and G. W. Procop, "Her-2/Neu Amplification in Breast Cancer. Stratification by Tumor Type and Grade," Am Journal of Clinical Pathology, Vol. 117, No. 6, 2002, pp. 916-921. doi:10.1309/4NTU-N6K4-F8JF-EWRX

[34] I. L. Andrulis, S. B. Bull, M. E. Blackstein, D. Sutherland, C. Mak, S. Sidlofsky, et al., Toronto Breast Cancer Study Group, "Neu/erbB-2 Amplification Identifies a Poor-
Prognosis Group of Women with Node-Negative Breast Cancer," Journal of Clinical Oncology, Vol. 16, No. 4, 1998, pp. 1340-1349.

[35] A. Traina, B. Agostara, L. Marasà, M. Calabrò, M. Zarcone and G. Carruba, "Her-2/Neu Expression in Relation to Clinicopathologic Features of Breast Cancer Patients," Annals of the New York Academy of Sciences, Vol. 1089, 2006, pp. 159-167. doi:10.1196/annals.1386.029

[36] A Harlozinska, J. K. Bar, R. Wenderski and M. Bebenek, Association with Tumor Phenotypes, "Relationship between c-erbB-2 Oncoprotein, Epidermal Growth Factor Receptor, and Estrogen Receptor Expression in Patients with Ductal Breast Carcinoma," In Vivo, Vol. 10, No. 2, 1996, pp. 217-222.

[37] S. A. Aziz, S. Pervez, S. Khan, N. Kayani, S. I. Azam and M. H. Rahbar, "Significance of Immunohistochemical Pattern for Prognosis in Human Breast Cancer," Pathology \& Oncology Research, Vol. 7, No. 3, 2001, pp. 190196. doi:10.1007/BF03032348

[38] S. Kariya, Y. Ogawa, A. Nishioka, T. Moriki, T. Ohnishi, S. Ito, Y. Murata and S. Yoshida, "Relationship between Hormonal Receptors, HER-2, p53 Protein, bcl-2, and MIB-1 Status and the Antitumor Effects of Neoadjuvant Anthracycline-Based Chemotherapy in Invasive Breast Cancer Patients," Radiation Medicine, Vol. 23, No. 3, 2005, pp. 189-194.

[39] A. E. Pinto, S. Andre, T. Pareira, S. Nobrega and J. Soares, "C-erbB-2 Oncoprotein Overexpression Identifies a Subgroup of Estrogen Receptor Positive (ER+) Breast Cancer Patients with Poor Prognosis," Annals of Oncology, Vol. 12, No. 4, 2001, pp. 525-33. doi:10.1023/A:1011163211802

[40] S. Kaptain, L. K. Tan and B. Chen, "Her-2/Neu and Breast Cancer," Diagnostic Molecular Pathology, Vol. 10, 3, 2001, pp. 139-152. doi:10.1097/00019606-200109000-00001

[41] S. Selvarajan, K. Y. Wong, K. S. Khoo, B. H. Bay and P. H. Tan, "Overexpression of c-erbB2 Correlates with Nuclear Morphometry and Prognosis in Breast Carcinoma in Asian women," Pathology, Vol. 38, No. 6, 2006, pp. 528533. doi:10.1080/00313020601024060

[42] S. Taucher, M. Rudas, R. M. Mader, M. Gnant, P. Dubsky, T. Bachleitner and S. Roka, "Do We Need Her2/Neu Testing for All Patients with Primary Breast Carcinoma?" Cancer, Vol. 98, No. 12, 2003, pp. 2547-2553. doi: $10.1002 /$ cncr. 11828

\section{List of Abbreviations}

Her2 = human epidermal growth factor receptor 2;

$\mathrm{PR}=$ progesterone receptor.

$\mathrm{ER}=$ estrogen receptor; 